\section{Child psychiatry, mental disorder and the law: is a more specific statutory framework necessary?}

\author{
R. POTTER and N. EVANS
}

Society generally is ambivalent about the responsibilities and rights of its young people. Although the past few decades have seen a social and judicial shift away from the power of parents to control their children, towards children's rights and parental responsibility, this trend is not sufficiently developed in relation to children with mental health problems for one to be confident that the rights of such young people are protected.

The authority to confine and compulsorily treat mentally disordered citizens derives from police powers and the parens patriae power of the state. However, the distinction between the two is not always evident when considering how the courts deal with children and young people with mental disorders, because of the strong element of paternalism that guides courts in these cases. According to UK law, children of 10 years old are fully accountable and responsible for their criminal activities; in contrast, a 17-year-old may not be able to refuse a minor medical procedure or have a tattoo. Bridge (1997) draws attention to this dilemma of acknowledging and respecting the child's autonomy, while at the same time having to care and take responsibility for the child. A parent's power to confine and treat a child in a psychiatric hospital against the child's wishes is seen as an extension of the parent's responsibility to care for the child (Neilsen v. Denmark [1989]). However, the tension between these competing ideas comes to the fore in adolescence as it is at this developmental stage that the tensions between the medical and legal conceptions of the young person's behaviour, symptoms, actions and responsibility are brought into the sharpest relief.

Children can be treated for mental disorder without their consent. This is true whether or not the child is competent. The legal framework for this is made up of a patchwork of statutory and case laws mainly formulated without the developmental needs of the child in mind. Moreover, the particular deficiencies and inconsistencies in service provision, and the competing pressures on services, professionals, families and the child, call for special consideration of the needs of this vulnerable group. For those of us working with children suffering from mental disorder, the current reform of the Mental Health Act 1983 offers an opportunity to improve the way in which the needs of these children are addressed.

\section{PROPOSED REFORM OF THE MENTAL HEALTH ACT 1983}

The Draft Mental Health Bill (Department of Health, 2002) does describe some additional safeguards for children who become subject to compulsory detention or admission under the Act. Parents must be consulted - or at least there will be an obligation to consult a parent, or any other person with parental responsibility for children up to 16 years old. However, it is proposed that young people aged 16-18 years cannot be detained or treated against their will with parental authority alone, but must be compulsorily admitted or treated under a Care and Treatment Order under the new Act. Therefore it is not adequate for parents to consent on their child's behalf, and this is written in terms of the young person not giving rather than refusing consent (which is significant in the context of the House of Lords decision in R. $v$. Bournewood [1998]). Moreover, it is suggested that the role of the Mental Health Act Commissioner might be extended to oversee that the rights of informal patients are also protected. However, it is unclear how this will be achieved.

\section{TREATMENT OF MENTAL DISORDER IN CHILDREN WITHOUT THEIR CONSENT}

It is appropriate that in most cases parents are empowered to make decisions on behalf of their children. However, when mental illness is present, intrafamilial relationships can become strained to the point that decision-making is difficult to achieve. Within the doctor-patient relationship the uneven distribution of power further distorts the decision-making process. Where there is evidence that a child needs to be compulsorily detained and treated under the Mental Health Act 1983, these difficulties are compounded. Particularly in relation to children, the ambiguity within the Act in the definition of mental disorder, risk, dangerousness and inability to selfcare makes it difficult for parents to challenge doctors' opinions.

Perhaps not surprisingly, psychiatrists often have tried to avoid using compulsory powers under the Mental Health Act 1983. Reasons for this may be the need to maintain collaboration with the child and to avoid perceived stigmatisation resulting from detention under the Act (Bridge, 1997). However, as Fennell (1992) argues, it is more the mental illness itself rather than the compulsory admission that leads to the stigma. Therefore, codes of practice (Department of Health \& Welsh Office, 1999) and academic commentators may well argue that children with mental disorder should be detained when clinically appropriate, but they also acknowledge that to do so may be 'swimming against the overwhelming tide of professional opinion not to use compulsory powers under the 1983 Act' (Fennell, 1996). Rather than state that the Mental Health Act 1983 should be used, it will be more useful to consider the reasons why it is not used and more importantly how the child's welfare and health can be promoted more effectively. Significantly, children who are refusing treatment and are therefore treated with parental authority alone have none of the statutory safeguards for the protection of their rights (Fennell, 1992, 1996). The Mental Health Bill adequately addresses none of these issues.

\section{THE LAW AND CONSENT}

There exists an apparent inconsistency in the law, in that young people under 18 years old can consent to treatment, but cannot refuse in the face of proxy consent by someone with parental responsibility (Re R [1991]; Re W [1993]). The Gillick case (Gillick $v$. West Norfolk and Wisbech Health Authority [1986]) was a landmark decision, which clarified what would be involved in order to satisfy the courts that 
a child is competent to consent to his or her own treatment. Although this imposed a higher standard for the child to meet than an adult facing the same decision, clinically the clarification has been useful. The child is expected to understand not only what the treatment involves and the consequences of consenting, refusing or taking an alternative course of treatment, but also the wider consequences, including the repercussions on family relationships. If a child is able to understand all this and come to a reasoned view having considered the balance of the arguments for each course of action, why then is this insufficient for the child to be able to consent to or refuse the treatment? Refusal might carry with it more serious and far-reaching consequences (Pearce, 1994); it might require a higher order of deliberation and decisionmaking (McCall-Smith, 1992); but if these hurdles are passed, it would appear illogical to allow a child to consent but not to refuse. The decision-making is then taken by an adult who is not required to consider the decision and its implications so deeply.

Moreover, neither the European Convention on Human Rights nor the Human Rights Act 1998 has been shown to have any teeth when it comes to protecting the rights of the child against the wishes of a parent. The current law allows the rights of the children themselves to be sidelined or disregarded. In the absence of the courts being prepared to consider meaningfully the criteria and circumstances in which a child can refuse treatment (in a Gillick-like judgment considering the refusal of treatment in minors), there is a need for statutory clarification. This has wider implications than for mental health alone, and therefore the Mental Health Bill does not - and perhaps could not be expected to - address this issue, being drafted with the mental health of adults in mind.

\section{CONCLUSION}

The legal framework relating to these vulnerable children, being largely borrowed

R. POTTER, MSc, LLM, N. EVANS, MSc, Brynffynnon Child and Family Service, Pontypridd and Rhondda NHS Trust, Pontypridd, UK

Correspondence: Dr R. Potter, Brynffynnon Child and Family Service, Merthyr Road, Pontypridd, Mid-Glamorgan CF37 4DD, UK. Tel: 01443 480540; fax: 01443480535

(First received 3 February 2003, final revision 23 April 2003, accepted 27 May 2003)

from that for adults, can never fully take account of the specific developmental needs of children, or of the differences, inconsistencies and, in particular, the multi-agency nature of children's services. These deficiencies in the legal framework for the treatment of children with mental disorder cannot be addressed by a simple add-on to adult mental health legislation: a more specific statutory framework is necessary. Only then will the law be able to address adequately the important issues for children. The legislation will need to ensure the joint planning and shared responsibility for children with mental illness and children who are 'difficult to place' because of their high-risk behaviour between social services and health and education. It will need to confront the thorny issues of how the child may be subject to de facto detention, and integrate sufficient safeguards to protect the child's own rights. In the current climate in which children's services operate, this more multi-agency approach would have the added advantage of opening the whole process to greater external scrutiny. There is the additional safeguard for the child provided by the involvement of other professionals who are able to take a different and perhaps broader view of the child's best interests.

The Mental Health Bill marks a shift away from caring for people with mental disorder towards controlling them. The Children Act 1989 was an attempt to address the needs of children by bringing together the laws relating to their care and their rights. In so doing there was an acknowledgement that these issues could only be addressed by a specific statutory framework. It is time to rethink how the law relating to children with mental disorder can most adequately meet their needs.

\section{DECLARATION OF INTEREST}

None.

\section{REFERENCES}

Bridge, C. (1997) Adolescents and mental disorder: who consents to treatment? Medical Law International, 3, 5 I -74 .

Department of Health (2002) Draft Mental Health Bill. London: Stationery Office.

Department of Health \& Welsh Office (1999) Code of Practice. Mental Health Act 1983. London: HMSO.

Fennell, P. (1992) Informal compulsion: the psychiatric treatment of juveniles under common law. Journal of Social Welfare and Family Law, 4, 3II-333.

Fennell, P. (1996) Treatment Without Consent: Law, Psychiatry and the Treatment of Mentally Disordered People since 1845. London: Routledge.

McCall-Smith, I. (1992) Consent to treatment in childhood. Archives of Disease in Childhood, $6 \mathbf{6 7}$ 1247-1248.

Pearce, J. (1994) Consent to treatment during childhood. The assessment of competence and avoidance of conflict. British Journal of Psychiatry, 165, 713-716.

Gillick v. West Norfolk and Wisbech Area Health Authority [1986] AC II2.

Neilsen v. Denmark [1989] II E.C.H.R. 175

R. v. Bournewood Community Mental Health NHS Trust ex parte $L$ (Secretary of State for Health and Others intervening) [1998] All ER 3289 (HL).

Re R (A Minor) (Wardship: Medical Treatment) [1991] 4 All ER 177.

Re W (A Minor) (Medical Treatment) [1993] All ER 627 (1993) I F.L.R. I. 